\title{
Fluid-Rock Interaction in the Lower \\ Crust based on Silicate Melt Inclusions in Garnet Granulite Xenoliths
}

B. NÉMETH ${ }^{1,2,5 *}$, K. TÖRÖK ${ }^{1}$, E. BALI $^{3}, Z^{2}$. ZAJACZ ${ }^{4}$, CS. SZABÓ $^{5}$

${ }^{1}$ Mining and Geological Survey of Hungary (*correspondence: bianca.nemeth@gmail.com, torok.kalman@mbfsz.gov.hu)

${ }^{2}$ MTA-ELTE Volcanology Research Group, Eötvös University, Budapest, Hungary

${ }^{3}$ Institute of Earth Sciences, University of Iceland, Iceland (eniko@hi.is)

${ }^{4}$ Section of Earth and Environmental Sciences, University of Geneva, Switzerland (Zoltan.Zajacz@unige.ch)

${ }^{5}$ Lithosphere Research Group, Eötvös University, Budapest, Hungary (cszabo@elte.hu)

Two alkali basalt hosted mafic garnet granulite xenoliths with primary silicate melt inclusions (SMIs) in their rockforming minerals were studied from the Plio-Pleistocene Bakony - Balatony-Highland Volcanic Field (Hungary). In contrast with majority of similar xenoliths from the area, these samples have nonequilibrium texture. The glass in the SMIs is dacitic-rhyolitic, with Mg-number up to 0.38 . These exclude the contribution of the host alkaline basalt in the formation of these SMI. On the other hand, the major and trace element composition of SMIs resembles the composition of early Miocene calc-alkaline magmas from the Carpathian Pannonian Region [1]. SMIs are enriched in Cs, $\mathrm{Rb}$ and $\mathrm{Pb}$, and are characterized by negative $\mathrm{Nb}$ and $\mathrm{Ta}$ anomalies. Such melt is usually typical of island arc volcanism [2]. The enrichment in fluid-mobile elements and the high $\mathrm{K}_{2} \mathrm{O}$ and $\mathrm{Na}_{2} \mathrm{O}$ content may indicate that the $\mathrm{H}_{2} \mathrm{O}$ rich melt of SMIs is formed by partial melting of a rock which was rich in a water-bearing mineral phase (e.g. biotite and/or amphibole). The chemical composition of SMIs and their host minerals can be modeled by a two stage process: 1) partial melting of a lower crustal mafic granulite and metasedimentary granulite mélange in the presence of C-O$\mathrm{H} \pm \mathrm{S} \pm \mathrm{N}$ fluids; 2) reequilibration of this "hybride melt" with a garnet-rich granulite wall rock. Individual SMIs in the studied samples preserve a snapshot of this dynamic process.

This study is part of a project that has received funding from the EU's H2020 research and innovation programme under grant agreement No 810980 .

[1] Harangi et al. (2001) J.Petrol. 42 (10), 1813-1843. [2] Pearce (1983) In: Hawkesworth \& Norry (Ed.) Continental basalts and mantle Xenoliths, Shiva, Nantwich, 230-249. 